\title{
PECULARITIES OF THE MULTIPLE REGRESSION METHOD APPLICATION IN THE INVESTIGATION OF CHINESE SPECIAL ECONOMIC ZONES
}

\author{
Anna KYLYMCHUK \\ Taras Shevchenko National University of Kyiv, Ukraine \\ elphenok@bigmir.net
}

\begin{abstract}
This article investigates the third generation special economic zones in China and their effectiveness factors. It considers economic and technological development zones both as forms of international cooperation and as ways of Chinese regional policy implementation. The functioning of the mentioned above zones is regarded in comparison with the high-tech development zones. Moreover, the work describes the main features of the multiple regression method application in the specific human geography study. Thus, this method is used to determine and verify the significance of the profitability factors of economic and technological zones. Furthermore, the article involves several recommendations how to use the constructed regression model in the similar special economic zones research of other countries.
\end{abstract}

Key words: special economic zone, economic and technological development zone, high-tech development zone, multiple regression.

DOI: http://dx.doi.org/10.17721/2413-7154/2016.75.69-73

UDC: [911.3:332.122(510-01)]:303.724.32

\section{ОСОБЛИВОСТІ ВИКОРИСТАННЯ МЕТОДУ РЕГРЕСІЙНОГО АНАЛІЗУ В ДОСЛІДЖЕННІ СПЕЦІАЛЬНИХ ЕКОНОМІЧНИХ ЗОН КИТАЮ}

\author{
Анна КИЛИМЧУК \\ Київський національний університет імені Тараса Шевченка, Україна \\ elphenok@bigmir.net
}

\begin{abstract}
Анотація: Стаття присвячена дослідженню факторів ефективності діяльності спеціальних економічних зон Китаю третього покоління. Вона розглядає зони економіко-технологічного розвитку одночасно як форму міжнародного співробітництва, так й інструмент реалізації регіональної політики КНР. Діяльність зон даного типу досліджується в порівнянні із зонами розвитку новітніх і високих технологій, що також відносяться до зон третього покоління. Водночас в роботі описуються особливості застосування методу множинної регресії для досягнення цілей конкретного суспільно-географічного дослідження. Так, даний метод застосовується для визначення та перевірки значущості чинників ефективності функціонування економіко-технологічних зон. Також частково описується можливість використання побудованої моделі для вивчення СЕЗ в інших країнах.

Ключові слова: спеціальна економічна зона, зона економіко-технологічного розвитку, зона новітніх і високих технологій, множинна регресія.
\end{abstract}

DOI: http://dx.doi.org/10.17721/2413-7154/2016.75.69-73

удк: [911.3:332.122(510-01)]:303.724.32

Вступ. Постановка проблеми. Китай на сьогодні $€$ лідером по кількості спеціальних економічних зон в світі, яких нараховується більше 500 [16]. Більшу частину з них складають зони третього покоління, які оріснтовані на інвестиційно-технологічний розвиток країни в цілому та окремих ii регіонів. До них належать зони економіко-технологічного розвитку (ЗЕТР) та зони новітніх і високих технологій (ЗНВТ). Перший тип представлений територіями, на яких діє спеціальний правовий режим здійснення економічної діяльності та надаються економічні преференції діючим підприємствам в широкому спектрі галузей господарства. Другий представляє собою особливі зони, метою створення яких є проведення досліджень та розробок 3 їх подальшою комерціалізацією,

(C) А. Килимчук a також розвиток окремих новітніх галузей, включаючи інформаційні технології, електроніку, фармацевтику, біотехнології тощо. Зазвичай ЗНВТ розташовуються поблизу університетів та інших наукових установ. В порівнянні із зонами економікотехнічного розвитку вони мають додаткові стимули та переваги в сфері інноваційної діяльності.

Ідея створення спеціальних економічних зон в КНР є запозиченою: аналоги технологічних зон такі, як технопарки, технополіси, наукові парки, інноваційні центри та бізнес інкубатори функціонують в понад 70 державах Європи, Азії, Африки, Америки та Австралії [4]. Однак, саме в Китаї даний тип зон, впроваджений 3 урахуванням специфіки країни, характеризується високими показниками економічної активності та вагомим значенням у загальнодержавному розвитку. Тому, на сьогодніш- 
ній день, питання забезпечення ефективності діяльності СЕ3, зокрема, китайський досвід, є актуальним та малодослідженим. При цьому, не менш важливою, залишається проблема вибору методики дослідження спеціальних економічних зон. Дана стаття є спробою часткової систематизації особливостей застосування методу множинної регресії щодо вивчення спеціальних технологічних зон Китаю.

Аналіз останніх досліджень і публікацій. Серед зарубіжних вчених розробка даної проблематики 3 використанням методу множинної регресії аналізу відображена в працях Р. Дейвіс [10], С. Паркер, К. С. Фун [3], Оувен Хо [9], Цзінь Ван [18], Ю-Інь Ву, Бі Джей Лью [1], Д. А. Ізотова [5] та інших. В українській школі суспільних географів застосування методологічного апарату математичної статистики для практичних потреб географії описано в працях О. І. Шаблія [11], О. Г. Топчієва [17], К. В. Мезенцева [7], К. А. Нємець, Ю. С. Брайчевського [2] та інших.

Мета і завдання дослідження. Метою статті $€$ визначення факторів ефективності діяльності спеціальних економічних зон в Китаї, а також розкриття деяких особливостей використання методу множинної регресії в суспільно-географічних дослідженнях. Досягнення поставленої мети потребує вирішення наступних завдань:

- Розкрити характері риси впровадження китайської концепції технологічних зон;

- Проаналізувати особливості використання методу регресійного аналізу в дослідженні спеціальних економічних зон;

- Дослідити фактори ефективності функціонування зон економіко-технологічного розвитку та провести їх порівняльний аналіз 3 чинниками діяльності зон високих технологій.

Виклад основного матеріалу. На початкових етапах впровадження економіко-технологічних зон в Китаї основною метою їх створення було сприяння, головним чином, розвитку високотехнологічних галузей промисловості, зосередження діяльності на масштабних інвестиційних проектах, стимулювання експорту та поліпшення інвестиційного клімату країни в цілому. На сьогоднішній день, їх ціль полягає у посиленні економічної співпраці розвинутого сходу з більш відстали провінціями та районами заходу і центру КНР. Зокрема, налагодження тісніших зв'язків та досягнення координованого зростання регіональної економіки [8]. Так, зокрема, завданнями зон економіко-технологічного розвитку $\epsilon$ трансферт i впровадження новітніх технологій в місцеву промисловість, а також будівництво інфраструктурних об'єктів міжнародного класу.

Досвід Китаю у впровадженні концепції спеціальних економічних зон вказує на те, що така зона може бути розташована в будь-якому географічному місці, де створені необхідні сприятливі умови для розвитку інвестиційного процесу й технологічного виробництва. Найяскравішим прикладом є зона економіко-технологічного розвитку в місті Лхаса Тибетського автономного району. Вона була заснована у 2001 році одночасно з будівництвом високогірної ділянки Цінхай-Тибетської залізниці, що з'єднала столицю Тибету з розвинутим сходом країни. Покращення транспортного положення зони позитивно вплинуло на показники їі діяльності. Так, в 2006 року після відкриття гілки Голмуд-Лхаса, ВВП зони зріс вдвічі. При цьому, в 2014 коли залізнична колія була продовжена на захід до пункту Шигадзе відбувся значний притік інвестицій i загальна кількість зареєстрованих підприємств в ЗНВТ Лхаса досягла 800 фірм.

В світовій практиці, в тому числі й в Україні, CE3 створюються, як правило, на прикордонних територіях, в портах та відкритих містах. Водночас, значна кількість (50 \%) спеціальних економічних зон в КНР розміщені у внутрішніх регіонах, значно віддалених від кордону i таких, що не мають безпосереднього виходу до моря. Варто зазначити, що особливістю Китаю на сьогоднішній день $є$ охоп-лення спеціальними економічними зонами усіх провінцій та автономних районів країни. При цьому, саме зони економіко-технологічного розвитку показали себе як досить дієвий інструмент регіональної політики. Так, темпи приросту основних макроекономічних показників зон центральних та західних регіонів вищі за відповідні в ЗНВТ розвинутого східного узбережжя. Вони забезпечують близько 30-40\% валової продукції, 30\% експортних та 20\% податкових надходжень, а також до 8-10\% зайнятості в регіоні [6]. Це свідчить про те, що політика збалансування регіонального розвитку, зокрема розбудови західного поясу відкритості та економічної активності, проведена китайським урядом, є досить ефективною.

Опис методики дослідження та здобутих емпіричних даних. Вибір методу множинної регресії в даній роботі обумовлений міждисциплінарним характером об'єкта дослідження, його складністю та наявністю різноманітних зв'язків із зовнішнім середовищем. Регресійний аналіз дає змогу провести незаангажоване дослідження та дати комплексну оцінку умовам, в яких функціонують спеціальні економічні зони в Китаї. Завдяки використанню даного методу стає можливим виявлення сукупної взаємної дії багатьох чинників на діяльність зон економіко-технологічного розвитку. В результаті ми отримуємо модель, що є наближеною до реальних умов і може бути використана для розробки прогнозів щодо подальшої ефективності функціонування СЕ3 в КНР та закордоном. Однак, для кожної окремої країни набір вхідних параметрів буде відрізнятись, зокрема це стосується показників, що відображають (характеризують) одні й ті самі чинники.

Так, згідно попередніх досліджень автора, саме для Китаю характерним є зосередження зон новітніх i високих технологій в регіонах 3 нижчим рівнем оплати праці, вищими показниками інвестиційної діяльності й одночасно наявністю наукової бази. При цьому найбільший внесок у величину кінцевого доходу зон складають в першу чергу такі параметри як ступінь розвитку інфраструктури, в тому числі 
транспортної. В умовах Китаю важливу роль відіграє залізничний транспорт, що представлений єдиною сформованою потужною мережею. Якщо ж обирати даний критерій для дослідження СЕЗ в інших країнах слід розглядати такий параметр, як довжина умовної мережі шляхів, тобто довжина мереж усіх видів транспорту, окрім авіаційного, перерахована в еквівалентну довжину залізничних доріг. Наприклад, в Японії майже відсутні вантажні перевезення залізницею, а в Свропі найрозвиненішою є мережа автобанів.

Варто зауважити, що досягнення найбільш об'єктивних результатів при застосуванні методу множинної регресії потребує якомога більшої повноти охоплення гіпотетичних факторів, загальне число яких не повинно перевищувати n-1, де n кількість спостережень (в нашому випадку кількість регіонів-реципієнтів ЗЕТР). Однак, щоб уникнути явища мультиколінеарності, тобто наявності лінійної залежності між декількома чинниками, що призводить до спотворення результатів, слід вдатися до редукції числа параметрів, що підлягають перевірці. Тому на етапі відбору гіпотетичних факторів варто застосовувати метод факторного аналізу, який дозволяє з численних груп однорідних показників сформувати декілька загальних факторів, шляхом об'єднання тих, між якими існує певна залежність [7] Варто пам'ятати, що при збільшенні або зменшенні кількості гіпотетичних факторів, результати аналізу будуть відрізнятись, адже даний метод показує взаємний вплив показників на досліджуване явище. Тому при появі додаткових чинників коефіцієнти біля одних і тих самих величин в рівнянні можуть бути дещо відмінними.

В даному дослідженні, в якості вхідних даних було обрано статистичні показники 31 адміністративної одиниці Китаю, 22 провінцій, 5 автономних районів та 4 міст центрального

підпорядкування, в яких функціонують зони економіко-технологічного розвитку. Серед групи загальноекономічних факторів були розглянуті такі критерії, як валовий регіональний продукт на душу населення, обсяг експорту іноземних підприємств, обсяги імпорту та експорту регіону, державні інфраструктурні інвестиції, індекси інвестиційних цін основного капіталу, індекси виробничих цін на промислову продукцію, обсяг витрат на кінцеве споживання продукції, рівень середньої заробітної плати в регіоні в цілому та на підприємствах іноземної власності, співвідношення іноземних та державних підприємств, кількість корпоративних та приватних фірм.

3 ряду демографічних факторів аналізувались чисельність населення, співвідношення міського i сільського населення, загальний приріст населення (природний+механічний).

3 групи науково-освітніх факторів були обрані показники рівня освіченості населення (кількість осіб 3 вищою та середньою освітою), кількість науково-дослідних інституцій, чисельність науководослідного персоналу).

3 групи показників, що характеризують транспорту доступність до уваги були взяті наступні: густота залізничної мережі, автомобільних та внутрішніх водних шляхів.

Для оцінки впливу вищезазначених показників на ефективність діяльності ЗНВТ використовувалось наступне рівняння:

$Y_{G}=\alpha+\beta_{1} \mathrm{X}_{1}+\beta_{2} \mathrm{X}_{2}+\ldots+\beta_{n} \mathrm{X}_{\mathrm{n}}+\varepsilon$,

де $\mathrm{Y}_{\mathrm{G}}$ - залежна змінна (в нашому випадку валовий внутрішній продукт ЗЕТР на кв.км. площі), $\mathrm{X}_{\mathrm{n}}$ - незалежна змінна або ж гіпотетичний фактор, можливий вплив якого перевіряється, $\beta$ - коефіцієнт, який відображає силу впливу відповідного фактора

Таблиия 1

Регресійні коефіцієнти факторів ефективності діяльності зон економіко-технологічного розвитку

\begin{tabular}{|l|r|r|r|r|r|r|}
\hline \multicolumn{2}{|c|}{ Beta } & \multicolumn{1}{c}{ Std.Err. } & \multicolumn{1}{c}{ Btd.Err. } & \multicolumn{1}{c}{$\mathrm{t}(8)$} & -level \\
\hline Interсерt & & & 2161,82 & 390,3715 & 5,53 & 0,0005 \\
\hline Густота автошляхів & 0,73704 & 0,114546 & 6,94 & 2,405 & 6,434 & 0,0002 \\
\hline $\begin{array}{l}\text { Кількість інших типів СЕ3 в } \\
\text { регіоні }\end{array}$ & 0,62966 & 0,100906 & 3,74 & 0,5988 & 6,24 & 0,0002 \\
\hline $\begin{array}{l}\text { Співвідношення міського i } \\
\text { сільського населення }\end{array}$ & $-0,74561$ & 0,140780 & $-0,92$ & 0,1735 & $-5,29$ & 0,0007 \\
\hline $\begin{array}{l}\text { Співвідношення підприємств } \\
\text { державної та іноземної власності }\end{array}$ & 0,70953 & 0,083650 & 2,43 & 0,0003 & 8,48 & 0,00002 \\
\hline Витрати на НдДКР & 1,45777 & 0,260373 & 2,64 & 0,0010 & 5,598 & 0,0005 \\
\hline $\begin{array}{l}\text { Обсяг кінцевого споживання } \\
\text { продукції }\end{array}$ & 2,17128 & 0,277248 & 1,3 & 0,0036 & 7,83 & 0,00005 \\
\hline ВВП на душу населення & 2,13519 & 0,454632 & 29,73 & 0,0001 & 4,69 & 0,0015 \\
\hline
\end{tabular}

Розраховано автором за даними статистики $[12,13,14]$ 
на залежну змінну, $\alpha$ - константа (незалежне мінімальне значення показника досліджуваного процесу / явища, дійсне поза впливом всіх зовнішніх чинників), $\varepsilon$ - величина так званого статистичного «шуму», що відображає вплив випадкових факторів, непередбачених обставин, величин, які 3 тієї чи іншої причини не були включені в досліджувану модель (вважається випадковою, значення якої прямує до нуля при врахуванні всіх істотних чинників) [2]. Слід зазначити, що коефіцієнт $\beta$ $\epsilon$ стандартизованим i використовується, якщо в рівняння включені змінні 3 різними одиницями вимірювання. Він показує лише відносний внесок кожного параметра - регресора в прогнозування залежної змінної. Для характеристики прогнозних значень служить простий коефіцієнт В, який показує наскільки зміниться залежна змінна при збільшенні кожного окремого фактора на одиницю. Розрахункові значення обох коефіцієнтів представлені у табл. 1.

Для визначення статистичної значимості отриманих результатів було враховано величину рівня значущості p (p-level), що відображає, яка частка спостережень підпадає під визначений вплив конкретного фактора. Загальноприйнятим рівнем значущості вважається p, що не перевищує 0,05 . Це говорить про те, що побудована регресійна модель описує понад 95\% спостережень [15, с. 20]. Для оцінки ступеня надійності (суттєвості) зв'язків, обумовлених кожним 3 факторів, використовувався критерій Стьюдента (t). Якщо його величина перевищує табличне значення, то результати аналізу вважаються надійними. 3 усього ряду змінних були відібрані регресори, для яких рівень значущості р не перевищує 0,05 i величина критерію Стьюдента $\mathrm{t}$ вище критичного (в даному випадку при t (8), де 8 - число ступенів свобо-ди і рівні значимості 0,05 табличне критичне значення критерію Стьюдента становить 2,3). В цілому результати вважаються достовірними та значущими. Про це свідчать також наступні показники:

- Коефіцієнт детермінації $\mathrm{R}^{2}=0,99$ - даний показник приймає значення від 0 до 1 і вказує на те, який відсоток спостережень описується впливом усіх включених в модель факторних змінних.

- Коефіцієнт Фішера $\mathrm{F}(22,8)=92$ використовується для оцінки значущості коефіцієнта детермінації, тобто відповідності закладених в регресійну модель зв'язків реально існуючим. Так як, критичне табличне значення для $\mathrm{F}(22,8)=3,12$, то отриманий коефіцієнт детермінації вважається значущим.

Оцінка та обговорення результатів. Відповідно до отриманих результатів доцільно стверджувати про сильний вплив трьох факторів на ефективність діяльності зон економіко-технологічного розвитку, для яких коефіцієнт $\beta>1$. Залежність між ВВП зон та показником кінцевого споживання продукції свідчить про переорієнтацію діяльності ЗЕTР на внутрішні ринки. До того ж, аналіз показав відсутність впливу регіонального експорту і незначний вплив імпорту на величину зонального ВПП, що також говорить про спрямованість економіко-технологічних зон до імпортозаміщення, на противагу зонам високих технологій, що орієнтовані на експорт.

Вплив регіонального валового внутрішнього продукту на ефективність діяльності зон обумовлений тим, що даний показник характеризує об'єм внутрішнього ринку. А відтак, чим ємкіше ринок, тим більше можливостей виробляти різнорідну продукцію і сприятливіші умови для функціонування спеціальних економічних зон.

Третім по силі впливу показником виявився обсяг витрат на науково-дослідницькі та дослідницько-конструкторські розробки, так як наукові дослідження сприяють розширенню випуску продукції вищої доданої вартості, що в свою чергу позитивно позначається на кінцевому доході ЗЕТР.

Решта параметрів характеризуються середнім впливом ( $\beta$ від 0,6 до 1$)$ на результативність діяльності економіко-технологічних зон. Найбільший внесок у величину валового доходу ЗЕТР складає рівень розвитку мережі автомобільних шляхів, що виражений в показнику густоти автошляхів. По-перше, даний вид транспорту відіграє провідну роль у віддалених районах КНР, що $\epsilon$ реципієнтами економіко-технологічних зон, але не забезпечені іншим транспортними мережами. По-друге, як зазначалось вище, ЗЕТР в порівнянні iз ЗНВТ більше орієнтовані на внутрішні ринки й відповідно для них характернішими є перевезення на невеликі відстані. Майже рівносильним по впливу із транспортним фактором виявився такий чинник, як рівень економічної свободи, виражений у співвідношенні державних та іноземних підприємств. При цьому тут відмічається обернена тенденція в порівнянні із зонами високих технологій, для яких переважання підприємств іноземної власності $€$ більш сприятливим аніж державних. Значимість державних підприємств для економікотехнологічних зон може бути пояснена першочергово зниженням рівня конкуренції 3 боку іноземних фірм в одному регіоні. До того ж, значна частина сфери послуг в Китаї залишається виключною прерогативою держави.

Наявність інших типів спеціальних економічних зон, з одного боку, зумовлює ефект технологізації, сприяючи трансферту технологій в середині конкретного регіону. А 3 іншого, кооперація між зонами та користування спільною інфраструктурою та ресурсною базою впливає на досягнення ефекту економії від масштабу й відповідно на підвищення ефективності функціонування.

Єдиний регресор, для якого характерна обернено пропорційна залежність із валовим доходом зон, це співвідношення міського i сільського населення. Відповідно, можна стверджувати, що вищі доходи притаманні 3ЕТР, які розташовані за межами урбанізованих міст, що також пов'язано із відсутністю конкуренції з боку фірм, що функціонують на територіях звичайного податкового режиму.

Bci інші показники не виявили впливу на ефективність функціонування ЗЕТР, або ж їх вплив 
відносно слабий $(\beta<1)$, й відповідно не були включені до моделі і не розглядались в аналізі.

Висновки. Отже, можна стверджувати, що математико-статистичний метод регресійного аналізу може бути використаний для досягнення різних цілей та реалізації різнотипних завдань в суспільно-географічних дослідженнях. Так, автором статті за допомогою даного методу було визначено фактори ефективності діяльності зон економіко-технологічного розвитку в Китаї. Це дало змогу провести компаративний аналіз 3 попередньо дослідженими чинниками та умовами функціонування зон новітніх і високих технологій. Отримані результати підтвердили основоположні гіпотетичні твердження щодо діяльності двох типів спеціальних економічних $30 \mathrm{H}$ третього покоління:

1. Найчисленніші два типи CE3 в Китаї, що $\epsilon$ досить подібними за функціонально-галузевою структурою, пільговим режимом та видами діяльності мають різну спрямованість: для ЗЕТР більш характерне імпортозаміщення, для ЗНВТ першочерговим завданням $€$ стимулювання експортних операцій;

2. На ефективність діяльності обох типів зон справляють значний вплив такі фактори, як масштаб внутрішнього ринку-реципієнта зони, виражений у регіональному ВВП, та державні витрати на науководослідну сферу;

3. Хоча геопросторове поширення економікотехнологічних зон в більшій мірі відповідає територіальному зосередженню зон новітніх технологій в Китаї, однак в своєму розміщенні вони все ж таки визначаються різними чинниками. Якщо для ЗНВТ важливими параметрами є нижчий рівень оплати праці в провінції та вищий ступінь розвитку залізничної мережі, то для ЗЕТР більш вагоме значення мають автомобільний транспорт та відсутність конкуренції з боку фірм звичайного податкового режиму.

\section{References:}

1. Bih Jane Liu, Yu-Yin Wu Development Zones in China:Are STIPs a Substitute for or a Complement to ETDZs? Access mode: https://www.ntpu.edu.tw/econ/files/.../20110308170007.pdf.

2. Brajčevskij Û.S. Vikoristannâ metodu regresìjnogo analìzu u suspìl’no-geografǐcnih doslìdžennâh na prikladì vivčennâ elektoral'noï povedìnki [The use of regression analysis in human-geographic studies: the case of electoral behavior analysis]. Ekonomichna ta Sotsialna Geografiya [Economic and Social Geography], 2014, Vol. 2 (70), pp.6869. (In Ukrainian).

3. Fung, K. C., Iizaka, H., Lee, J. and Parker, S. Determinants of U.S. and Japanese foreign investment in China. Asian Development Bank Institute, 2000. Access mode: http://people.ucsc.edu/ kcfung/fdidet.pdf.

4. International Association of Science Parks and Areas of Innovation. Access mode: http://www.iasp.ws/bycountry

5. Izotov D.A. Zony s l'gotnym režimom KNR: prostranstvennaâ koncentraciâ i rol' vo vnešnej torgovle [Zones with China's concessional regime: spatial concentration and foreign trade contribution]. Èkonomika regiona [Economy of region], 2013, no.1, pp. 123-132. (In Russian).

6. Kilimčuk A.A. Special'nye èkonomičeskie zony kak klûčevoj faktor razvitiâ mestnoj èkonomiki Kitaâ [Special economic zones as a key factor of local economic development in China]. Aziatsko-Tihookeanskij region:èkonomika, politika i pravo [Pacific Rim: Economics, Politics, Law], 2015, no.1 (32), pp. 33-45. (In Russian).

7. Mezencev K.V. Pro vikoristannâ faktornogo analìzu v regìonal'nih doslìdžennâh [The use of factor analysis in regional studies]. Ekonomichna ta Sotsialna Geografiya [Economic and Social Geography], 2002, Vol. 53, pp. 21-27. (In Ukrainian).

8. National Economic and Technological Development Zones. Access mode: http://www.china.org.cn/english/ SPORT-c/76751.htm

9. Owen C. H. Ho. Determinants of foreign direct investments in China: a sectoral analysis. Access mode: http:// uwa.edu.au/_data/assets/pdf_file/0019/.../04_18_Ho.pdf.

10. Ronald B. Davies The Impact of Special Economic Zones on Exporting Behavior. Access mode: irserver.ucd. ie/bitstream/handle/10197/.../WP15 28.pdf?...1

11. Šablìj O.İ. Matematičnì metodi v social'no-ekonomičnìj geografï [Mathematical methods in social and economic geography]. L’vìv, 1994, 304 p. (In Ukrainian).

12. Sheng Laiyun China Statistical Yearbook, Beijing, China, 2013, pp. 18-33.

13. Sheng Laiyun China Statistical Yearbook, Beijing, China, 2012, pp. 55-69.

14. Shi Rong Yao China Development Zones Yearbook, Beijing, 2012, 360 p. (In Chinese)

15. Sykes, A.O. An Introduction to Regression Analysis. Coase-Sandor Institute for Law \& Economics Working Paper No. 20, 1993. Access mode: http://chicagounbound.uchicago.edu/law and economics/51/

16. The official website of China Association of Development Zone. Available at: www.cadz.org.cn/

17. Topčî̀v O.G. Suspil’no-geografičnì doslidžennâ: metodologîa, metodi, metodiki [Socio-geographical research, methodology, methods, techniques]. Odessa, 2005, 632 p. (In Ukrainian)

18. Wang J. The Economic Impact of Special Economic Zones: Evidence from Chinese Municipalities. Access mode: http://se.shufe.edu.cn/upload/_info/42910_1001270253311.pdf 